\section{Fungicides as Foliar Sprays or Rooting Cube Soaks in Propagation of Poinsettia}

\author{
D.M. Benson \\ Department of Plant Pathology, North Carolina State University, \\ Raleigh, NC 27695- 7616
}

Additional index words. Euphorbia pulcherrima, Rhizoctonia solani, rhizoctonia stem rot, benomyl, chlorothalonil, flutolanil, iprodione, metalaxyl, metalaxyl + benomyl

Abstract. Several fungicides, including benomyl, flutolanil, iprodione, metalaxyl, and a mixture of metalaxyl and benomyl that control rhizoctonia stem rot (Rhizoctonia solani Kuhn) of poinsettia (Euphorbia pulcherriman Willd. ex Kl.) were evaluated for inhibition of poinsettia root initials and suppression of root elongation. Fungicides were applied as either foliar sprays to poinsettia cuttings in rooting cubes or as soaks of rooting cubes before sticking of cuttings. Rooting cube soaks of iprodione and benomyl and fungicide sprays of iprodione, benomyl, and chlorothalonil inhibited root initiation as measured by root counts 28 days after sticking cuttings. However, root elongation as measured by root rating was similar for all fungicides and the untreated control at 28 days. Plant height of rooted poinsettia cuttings transplanted to $400-\mathrm{cm}^{3}$ pots was significantly less $(P=0.05)$ only for cuttings sprayed initially with iprodione, but not for rooting cubes soaked in iprodione 58 days after transplanting. The inhibitory effect of other fungicides on root initiation did not appear to affect plant growth once plants were transplanted. Chemical names used: methyl 1-(butyl-carbamoyl)-2-benzimidazolecarbamate (benomyl); tetrachloroisophthalonitrile (chlorothalonil); $N$-[3-(methylethoxy)phenyl]-2-(trifluoromethyl)benzamide (flutolanil); 3-(3,5dichlorophenyl)- $N$-(lmethylethyl)-2,4-dioxo-l-imidazolidinecarboxamide (iprodione); $N$-(2,6-dimethylphyenyl)- $N$-(methoxyacetyl) alanine methyl ester (metalaxyl).

Recently, several fungicides including benomyl (Benlate SOW, E.I. DuPont de Nemours Co., Wilmington, Del.), chlorothalonil (Daconil 2787 40.4F, ISK-Biotech Corp., Mentor, Ohio), flutolanil (SN 84364 SOW, Nor-Am Chemical Co., Wilmington), iprodione (Chipco 26019 50W, Rhone-Poulenc Ag. Co., Research Triangle Park, N.C.), and metalaxyl + benomyl (Varsity 42W, CibaGeigy Agricultural Division, Greensboro, N.C.) were found to be effective in control

Received for publication 30 Sept. 1991. Accepted for publication 13 Apr. 1992. This research was supported by the North Carolina Agr. Res. Serv., North Carolina State Univ., Raleigh, N.C., and, in part, by grants from the Fred C. Gloeckner Foundation, New York and Smithers-Oasis, Kent, Ohio. I thank Billy I. Daughtry for his technical assistance. I also thank Marvin Williams for photographic assistance; Fairview Greenhouses \& Garden Center, Raleigh, N.C., for providing stock poinsettia plants; Smithers-Oasis, Kent, Ohio, for providing Rootcubes; and the chemical companies listed in the materials and methods for providing test fungicides. Use of tradenames does not imply endorsement by the North Carolina Agr. Serv. of the products named nor criticism of similar ones not mentioned. This publication also reports research involving pesticides. It does not contain recommendations for their use, nor does it imply that the uses discussed here have been registered. All uses of pesticides must be registered by appropriate state and federal agencies before they can be recommended. The cost of publishing this paper was defrayed in part by the payment of page charges. Under postal regulations, this paper therefore must be hereby marked advertisement solely to indicate this fact. liar sprays and rooting cube soaks of poinsettias in rooting cubes (Oasis Rootcubes,
Smithers-Oasis, Kent, Ohio) were efficacious and prevented colonization of rooting cubes by $R$. solani. Rooting cube soaks used less fungicide than sprays, and application of soaks resulted in less worker and environmental exposure.

Poinsettia propagators are reluctant to use fungicides in propagation because previous research with fungicides, including benomyl, showed delayed or suppressed root development in poinsettia (Boodley, 1968; Lee et al., 1983; Peterson, 1981). The endemic nature of rhizoctonia stem rot and the potential for significant plant losses in poinsettia suggests a need for fungicides in the pest management strategy for this crop. The present research was initiated to evaluate the effect of fungicides efficacious for control of rhizoctonia stem rot on rooting of poinsettias in propagation and subsequent growth after potting.

Rooting cubes (Oasis Rootcubes) were either soaked in water or in fungicide suspension to saturation. Since a dry five-cube strip absorbed $200 \mathrm{ml}$, a fungicide application rate of $947 \mathrm{ml} / 929 \mathrm{~cm}^{2}$ was chosen in which $24 \mathrm{ml}$ of fungicide suspension was added to $176 \mathrm{ml}$ of water that each dry, fivecube strip absorbed completely before 'Gutbier V-14 Glory' poinsettia cuttings taken from stock plants were stuck. Fungicides tested and rate of product used were benomyl (Benlate 50W, $1.2 \mathrm{~g} \cdot$ liter $^{-1}$ ), chlorothalonil (Daconil 2787 40.4F, $1.8 \mathrm{ml} \cdot \mathrm{liter}^{-1}$ ), flutolanil (SN 84364 50W, $1.2 \mathrm{~g} \cdot$ liter $^{-1}$ ), iprodione (Chipco 26019 50W, 1.2 g.liter ${ }^{-1}$ ), metalaxyl (Subdue 2E, $0.33 \mathrm{ml} \cdot \mathrm{liter}^{-1}$ ), and metalaxyl + benomyl (Subdue $2 \mathrm{~W}+$ Benlate $40 \mathrm{~W}$, Varsity $42 \mathrm{~W}, 1.2 \mathrm{~g} \cdot$ liter $\left.^{-1}\right)$. Fun-

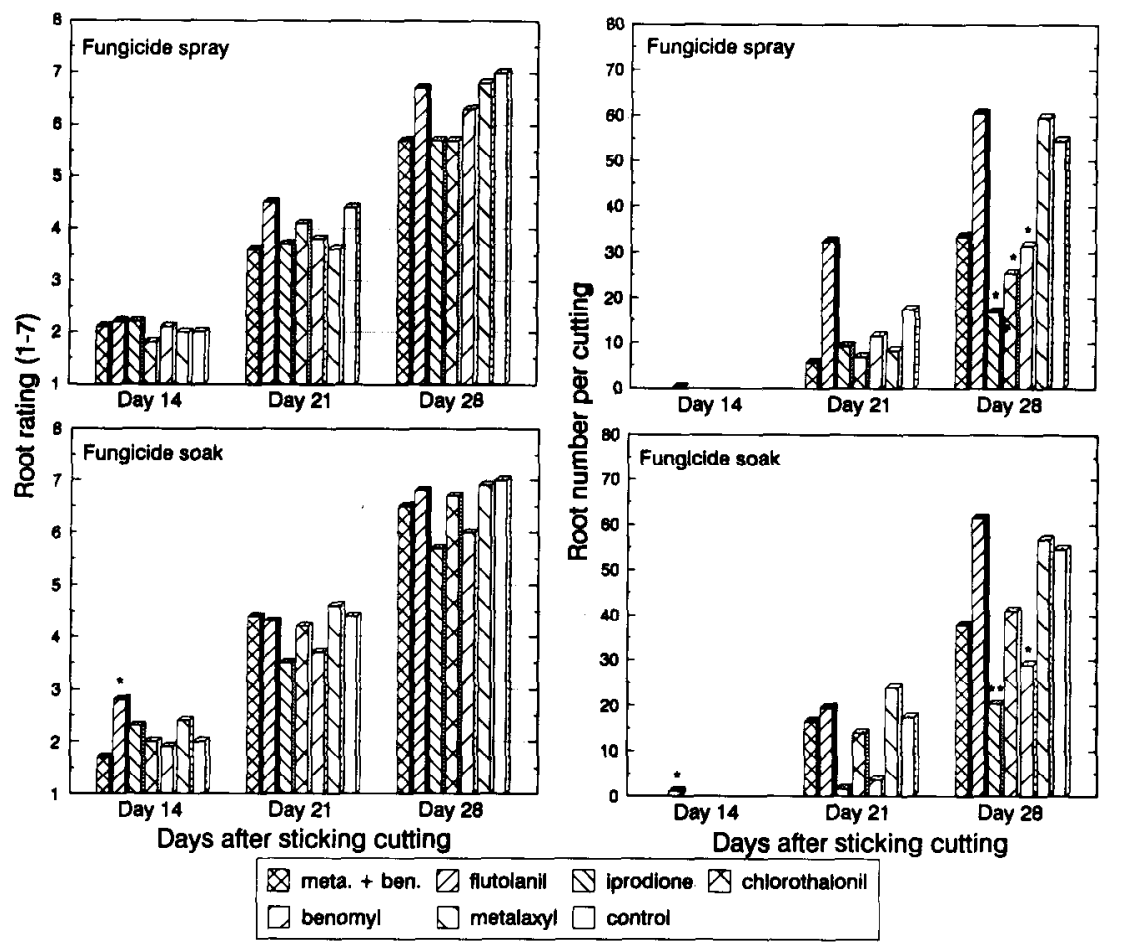

Fig. 1. Root rating and root count for poinsettia cuttings at 14, 21, and 28 days after sticking for poinsettias sprayed with fungicide or for poinsettias in rooting cubes soaked in fungicide. A single asterisk above a bar for a fungicide indicates a significant difference from the untreated control at $P$ $=0.05$, while a double asterisk indicates difference at $P=0.01$ based on linear contrast comparisons generated from an analysis of the data with PROC GLM of PC SAS (see Table 1). 
Table 1. Analysis of variance results for root rating and root count over three sampling dates for poinsettia cuttings treated with fungicides applied as foliar sprays or rooting cube soaks.;

\begin{tabular}{|c|c|c|c|c|}
\hline Source of variation & $\mathrm{df}$ & MS & F value & $\operatorname{Pr}>\mathrm{F}$ \\
\hline \multicolumn{5}{|c|}{ Root rating at 14 days } \\
\hline Replicative (Rep) & 1 & 0.0077 & 0.03 & 0.8530 \\
\hline Treatment (Trt) & 12 & 0.7974 & 3.57 & 0.0002 \\
\hline Rep $\times$ Trt & 12 & 0.2077 & 0.93 & 0.5193 \\
\hline \multicolumn{5}{|l|}{ Linear contrasts } \\
\hline Sprays vs. soaks & 1 & 0.4083 & 1.97 & 0.1862 \\
\hline Flutolanil spray vs. fluto. soak & 1 & 1.8000 & 8.67 & 0.0123 \\
\hline Flutolanil soak vs. control & 1 & 3.2000 & 15.4 & 0.0020 \\
\hline \multicolumn{5}{|c|}{ Root count at 14 days } \\
\hline Rep & 1 & 0.3769 & 0.93 & 0.3362 \\
\hline Trt & 12 & 0.9333 & 2.31 & 0.0117 \\
\hline $\operatorname{Rep} \times \operatorname{Trt}$ & 12 & 0.6769 & 1.68 & 0.0827 \\
\hline \multicolumn{5}{|l|}{ Linear contrasts } \\
\hline Sprays vs. soaks & 1 & 0.6750 & 1.00 & 0.3377 \\
\hline Flutolanil spray vs. fluto. soak & 1 & 4.0500 & 5.98 & 0.0308 \\
\hline Flutolanil soak vs. control & 1 & 6.0500 & 8.94 & 0.0113 \\
\hline \multicolumn{5}{|c|}{ Root rating at 21 days } \\
\hline Rep & 1 & 2.4923 & 6.11 & 0.0150 \\
\hline Trt & 12 & 1.5397 & 3.78 & 0.0001 \\
\hline Rep $\times$ Trt & 12 & 0.8756 & 2.15 & 0.0197 \\
\hline \multicolumn{5}{|l|}{ Linear contrasts } \\
\hline Sprays vs. soaks & 1 & 1.6333 & 1.87 & 0.1971 \\
\hline Metalaxyl spray vs. meta. soak & 1 & 5.0000 & 5.71 & 0.0342 \\
\hline Iprodione soak vs. control & 1 & 4.0500 & 4.63 & 0.0526 \\
\hline \multicolumn{5}{|c|}{ Root count at 21 days } \\
\hline Rep & 1 & 6.469 & 0.04 & 0.8360 \\
\hline Trt & 12 & 763.1 & 5.08 & 0.0001 \\
\hline $\operatorname{Rep} \times \operatorname{Trt}$ & 12 & 485.2 & 3.23 & 0.0006 \\
\hline \multicolumn{5}{|l|}{ Linear contrasts } \\
\hline Sprays vs. soaks & 1 & 23.4 & 0.05 & 0.8298 \\
\hline Iprodione soak vs. control & 1 & 1248.2 & 2.57 & 0.1347 \\
\hline Benomyl soak vs. control & 1 & 952.2 & 1.96 & 0.1866 \\
\hline \multicolumn{5}{|c|}{ Root rating at 28 days } \\
\hline Rep & 1 & 1.731 & 2.42 & 0.1229 \\
\hline Trt & 12 & 2.677 & 3.74 & 0.0001 \\
\hline $\operatorname{Rep} \times \operatorname{Trt}$ & 12 & 2.597 & 3.63 & 0.0001 \\
\hline \multicolumn{5}{|l|}{ Linear contrasts } \\
\hline Sprays vs. soaks & 1 & 2.408 & 0.93 & 0.3546 \\
\hline \multicolumn{5}{|c|}{ Root count at 28 days } \\
\hline Rep & 1 & 0.1923 & 0.00 & 0.9774 \\
\hline $\mathrm{Trt}$ & 12 & 2603.8 & 10.9 & 0.0001 \\
\hline Rep $\times$ Trt & 12 & 538.2 & 2.26 & 0.0140 \\
\hline \multicolumn{5}{|l|}{ Linear contrasts } \\
\hline Sprays vs. soaks & 1 & 291.4 & 0.54 & 0.4760 \\
\hline Benomyl spray vs. control & 1 & 2668.1 & 4.96 & 0.0459 \\
\hline Benomyl soak vs. control & 1 & 3302.5 & 6.14 & 0.0291 \\
\hline Chlorothalonil spray vs. control & 1 & 4263.2 & 7.92 & 0.0156 \\
\hline Iprodione spray vs. control & 1 & 7106.5 & 13.2 & 0.0034 \\
\hline Iprodione soak vs. control & 1 & 5848.2 & 10.9 & 0.0064 \\
\hline
\end{tabular}

${ }^{2}$ Linear contrasts for spray vs. soak application of fungicides are reported along with contrasts for significant individual fungicide effects and for two nonsignificant contrasts with low root count compared to the control.

Table 2. Effect of several fungicides applied as a foliar spray or as a rooting cube soak to ' $\mathrm{V}-14$ Glory' poinsettia cuttings on subsequent plant height 30 and 58 days after transplanting of rooted cuttines.

\begin{tabular}{|c|c|c|c|c|}
\hline \multirow[b]{3}{*}{ Treatment } & \multicolumn{4}{|c|}{ Plant ht $(\mathrm{cm})^{2}$} \\
\hline & \multicolumn{2}{|c|}{30 days } & \multicolumn{2}{|c|}{58 days } \\
\hline & Spray & Soak & Spray & Soak \\
\hline Benomyl & $12.2 \mathrm{bc}$ & $13.3 \mathrm{abc}$ & $23.2 \mathrm{abc}$ & $22.6 \mathrm{abc}$ \\
\hline Chlorothalonil & $13.3 \mathrm{abc}$ & $12.2 \mathrm{bc}$ & $22.7 \mathrm{abc}$ & $20.8 \mathrm{~cd}$ \\
\hline Flutolanil & $14.5 \mathrm{a}$ & $14.7 \mathrm{a}$ & $23.6 \mathrm{abc}$ & $23.9 \mathrm{ab}$ \\
\hline Iprodione & $11.7 \mathrm{c}$ & $14.5 \mathrm{a}$ & $19.4 \mathrm{~d}$ & $23.5 \mathrm{abc}$ \\
\hline Metalaxyl & $12.4 \mathrm{bc}$ & $14.2 \mathrm{a}$ & $21.5 \mathrm{bcd}$ & $23.9 \mathrm{ab}$ \\
\hline Metalaxyl + benomyl & $13.5 \mathrm{ab}$ & $14.3 \mathrm{a}$ & $22.5 \mathrm{abc}$ & $25.3 \mathrm{a}$ \\
\hline Untreated control & \multicolumn{2}{|c|}{$14.5 \mathrm{a}$} & \multicolumn{2}{|c|}{$23.2 \mathrm{abc}$} \\
\hline
\end{tabular}

${ }^{2}$ Mean separation for plant heights within a sample date by Wailer-Duncan $\mathrm{k}$ ratio: $\mathrm{k}=100, P=$ 0.05 . See text for fungicide rates used. gicides were also applied as foliar sprays after poinsettia cuttings were stuck in the rooting cubes. Poinsettia cuttings were sprayed to runoff ( $\approx 60 \mathrm{ml}$ per five-cube strip) with the test fungicide and allowed to dry before strips of cuttings were placed on a mist bench. Cuttings were misted 2 min every hour from 7 AM to 7 PM initially, then 2 min every 3 $\mathrm{h}$ daily thereafter. Daily temperatures during the propagation experiment were mean $21.4 \mathrm{C}$, average maximum $22.9 \mathrm{C}$, and average minimum 19.7C. There were two replications of five cuttings per strip per sampling date of each treatment, including an untreated control, arranged in a randomized complete-block design. The experiment was repeated twice with similar results.

After 14, 21, and 28 days, two replications of each treatment were chosen randomly and rated for rooting and number of roots. An estimate of root elongation was based on a rating where $1=$ no callose formed on cutting, 2 = callose formation, 3 = callose and root initials present, $4=$ roots $>1$ $\mathrm{mm}$ long, $5=$ roots through one side of rooting cube, $6=$ roots through two sides of rooting cube, and $7=$ roots through three sides of rooting cube. Root count was also determined at each sampling date for roots $>1 \mathrm{~mm}$ in length. Root count represented the effect of fungicides on root initiation. Data were analyzed with PROC GLM and linear contrast comparison (PC-SAS, SAS Institute, Gary, N.C.). On day 28, two extra replications of each treatment (total 10 cuttings) were transplanted individually to 400$\mathrm{cm}^{3}$ pots containing Metro-Mix 260 (W.R. Grace, Cambridge, Mass.) and grown for 8 weeks without pinching. Plants were fertilized weekly with $200 \mathrm{mg}$ N/liter (21N-7P$7 \mathrm{~K})$. Plant height was measured at 30 and 58 days.

No significant difference was found between foliar spray and rooting cube soak application methods of fungicides for root rating or root count on poinsettia cuttings at any sampling date (Table 1). Individual fungicides applied as sprays or rooting cube soaks were compared to the control for their effect on root rating and root count with results for significant effects along with the analysis of variance (ANOVA) for each sampling date listed in Table 1 and indicated as an asterisk over the fungicide bar in Fig. 1.

Differences in root rating and root count among treatments after 14 days were small. Cuttings in cubes treated with the flutolanil soak had higher root ratings and significantly more roots $(P=0.05)$ than those in cubes treated with the flutolanil spray, but only the cuttings in cubes with the flutolanil soak had higher rooting or more roots $(P=0.05)$ than the untreated control (Fig. 1). After 21 days, differences in treatments with flutolanil were not apparent, but root rating for cuttings in cubes soaked with metalaxyl were significantly higher $(P=0.05)$ than for similar cuttings sprayed with metalaxyl. However, ratings for cuttings in cubes soaked with metalaxyl were not different than those in untreated cubes. No significant differences were 
found in root count among treatments at 21 days.

After 28 days, there were no differences in root rating among treatments (Fig. 1). Root counts for cuttings in cubes treated with soaks of iprodione or benomyl and for cuttings sprayed with iprodione, chlorothalonil, and benomyl were significantly lower $(P=0.05)$ than for the untreated control (Fig. 1). The greater reduction in root counts for cuttings in fungicide spray treatments compared to those in soak treatments, in general, may be due to the actual amount of uptake of the fungicide by the cutting. In the rooting cube soak, the fungicide did not contact the cutting except at the insertion point in the cube; thus, little uptake of fungicide would be expected until rooting occurred. In contrast, cuttings would be expected to take up much more fungicide when sprays were applied directly to cuttings.
After rooted cuttings were transplanted and grown for 30 days, those treated with sprays of benomyl, iprodione, and metalaxyl, or with soaks of chlorothalonil were not as tall ( $P$ $=0.05$ ) as the untreated controls (Table 2). However, at 58 days after transplanting, only poinsettias from the iprodione spray treatment were significantly shorter $(P=0.05)$ than the control plants (Table 2).

Several fungicides including flutolanil, metalaxyl, and metalaxyl + benomyl caused no reduction in root rating or root counts when poinsettias were sprayed or rooting cubes were soaked in these fungicides at sticking. Soaks of benomyl and iprodione, and sprays of benomyl, chlorothalonil, and iprodione suppressed the number of roots formed but not the overall root rating. Apparently, root initiation is affected to a greater extent by these fungicides than subsequent root elongation. All inhibitory effects, as measured by root rating or root counts, were overcome by 58 days after transplanting, except for poinsettia cuttings sprayed with iprodione. These results suggest that most of the fungicides tested can be used safely in propagation of poinsettias when rhizoctonia stem rot threatens the crop.

\section{Literature Cited}

Benson, D.M. 1990. Control of Rhizoctonia stem rot of poinsettia during propagation with fungicides that prevent colonization of rooting cubes by Rhizoctonia solani. Plant Dis. 75:394-398.

Boodley, J.W. 1968. Poinsettia propagation and fungicides. New York State Plower Growers Bul. 274:4-5.

Lee, L.W., K.C. Sanderson, and J.G. Williams. 1983. Effect of fungicides applied to polyurethane propagation blocks on rooting of poinsettia cuttings. HortScience 18:359-360.

Peterson, J.C. 1981. More perspectives on the use of fungicides during poinsettia propagation. Ohio Florist Assn. Bul. 622:7-8. 